\title{
ANALISIS BUKU MATEMATIKA SISWA SMP KURIKULUM 2013
}

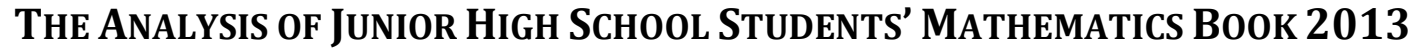 CURriculum}

\author{
Ilham Rizkianto ${ }^{1}$ dan Rusgianto Heri Santosa ${ }^{2}$ \\ 1Departemen Pendidikan Matematika, Universitas Negeri Yogyakarta \\ Sleman, Daerah Istimewa Yogyakarta, Indonesia \\ ilham_rizkianto@uny.ac.id \\ ${ }^{2}$ Departemen Pendidikan Matematika, Universitas Negeri Yogyakarta \\ Sleman, Daerah Istimewa Yogyakarta, Indonesia \\ santosa_rh@yahoo.co.id
}

\begin{abstract}
Abstrak
Penelitian ini memiliki tujuan untuk memformulasikan masukan sebagai bahan pertimbangan dalam penyempurnaan buku matematika siswa SMP kurikulum 2013. Sehingga nantinya kesalahan-kesalahan yang ditemukan dalam buku matematika siswa SMP kurikulum 2013 dapat diminimalisisr dan layak dipakai oleh siswa. Jenis penelitian ini adalah penelitian deskriptif analitik, yakni suatu penelitian yang bertujuan untuk memberikan gambaran tentang realitas pada objek yang diteliti secara objektif. Penelitian ini menekankan pada satu variabel yaitu kebenaran konsep pada buku matematika siswa SMP kurikulum 2013. Hasil analisis menunjukkan bahwa dalam buku matematika siswa SMP kurikulum 2013 masih terdapat banyak kesalahan. Kesalahan ini berupa kesalahan dalam penulisan maupun dalam merumuskan konsep pembelajaran matematika.

Kata Kunci: analisis buku, buku matematika siswa, kurikulum 2013, pembelajaran matematika.
\end{abstract}

\begin{abstract}
The aim of this present study is to formulate suggestions as a consideration in improving junior high school students' mathematics book 2013 curriculum. Later on, the mistakes found in the book can be minimalize and suitable to be used by students. The sort of this study is a analitic descriptive research, namely a research that intends to give representations about reality towards objects that have been studied objectively. This research study stresses in one variable, namely the truth concept in junior high school students' mathematics book 2013 curriculum. The result of the analysis shows that in Junior High School students' mathematics textbook 2013 curriculum was found many mistakes. The mistakes includes wrong spelling in written the words and wrong formulation of mathematics learning concepts.

Keyword: book analysis, students' mathematics book, 2013 curriculum, mathematics learning.
\end{abstract}

\section{Pendahuluan}

Pengembangan

merupakan

Kurikulum

langkah

Kurikulum

Pengembangan

Kompetensi yang telah dirintis pada tahun
2004 dan KTSP 2006 yang mencakup kompetensi sikap, pengetahuan, dan keterampilan secara terpadu. Kurikulum 2006 atau yang dikenal dengan KTSP dikembangkan menjadi Kurikulum 2013 
didasari pemikiran tentang tantangan masa depan, persepsi masyarakat, perkembangan pengetahuan dan pedagogi, kompetensi masa depan, dan fenomena negatif yang mengemuka. Perbedaan antara kurikulum 2013 dengan kurikulum sebelumnya salah satunya adalah adanya buku siswa dan buku guru yang sudah disediakan oleh pemerintah pusat sebagai buku wajib sumber belajar di sekolah.

Buku siswa menjabarkan usaha yang harus dilakukan siswa untuk mencapai kompetensi yang diharapkan. Dalam proses belajar, siswa dipacu untuk memperoleh informasi dari berbagai sumber belajar yang tersedia di sekitarnya. Oleh karenanya, peran guru sangat penting dalam meningkatkan dan menyesuaikan daya serap siswa dengan ketersedian kegiatan pada buku tersebut. Guru diharapkan dapat memperkayanya dengan kreasi dalam bentuk kegiatankegiatan lain yang sesuai dan relevan yang bersumber dari lingkungan sosial dan alam daerah masing-masing. Dengan demikian, guru sebagai pengendali utama di dalam proses belajar mengajar di kelas perlu mencermati terlebih dahulu terhadap buku siswa maupun buku pegangan guru yang sudah disediakan pemerintah. Hal ini diperlukan mengingat buku yang disediakan oleh pemerintah ditujukan untuk keperluan skala nasional. Dengan demikian, sebelum menggunakan di kelas, tentunya guru diharapkan sudah membaca dan mencermati dengan melakukan analisis buku terlebih dahulu. Hal ini dimaksudkan agar jika terdapat ketidaksesuaian atau ketidaktepatan yang ada dalam buku tersebut, dapat dilakukan langkah-langkah tindak lanjut untuk mengatasinya lebih awal.

Walaupun dihentikan sementara, kurikulum 2013 akan diterapkan kembali setelah mengalami proses penyempurnaan. Salah satu aspek kurikulum 2013 yang sangat perlu disempurnakan adalah buku teks, baik buku guru maupun buku siswa karena pada penerapan kurikulum 2013, buku teks tersebut wajib digunakan sebagai acuan utama. Hal ini sejalan dengan Peraturan Pemerintah Nomor 19 Tahun 2005 tentang Standar Nasional Pendidikan bahwa buku teks pelajaran termasuk ke dalam sarana pendidikan yang perlu diatur standar mutunya, sebagaimana juga standar mutu pendidikan lainnya, yaitu standar isi, standar proses, standar kompetensi lulusan, standar pendidikan dan kependidikan, standar sarana dan prasarana, standar pengelolaan, standar pembiayaan, dan standar penilaian pendidikan.

Namun, kenyataan di lapangan menunjukkan bahwa banyak keluhan yang dipaparkan guru terkait dengan buku matematika siswa kurikulum 2013 ini. Guru memaparkan bahwa masih banyak ditemukan kesalahan konsep dalam pembelajaran. Kesalahan konsep yang berlanjut akan merusak tatanan konstruksi kognitif siswa tentang matematika. Karena matematika merupakan ilmu yang terstruktur, kesalahan konsep dalam 
mempelajarinya akan membuat bangunan

ilmu menjadi rapuh. Oleh karena itu, perlu dilakukan tindakan konkrit yang dapat membantu guru dan juga siswa dalam mempelajari matematika.

Melihat pentingnya buku siswa dalam pembelajaran matematika, perlu dilakukan kajian terhadap buku matematika siswa yang digunakan dalam kurikulum 2013, maka peneliti mengangkat judul "Analisis Buku Matematika Siswa SMP Kurikulum 2013".

Adapun tujuan dari penelitian ini adalah untuk memformulasikan masukan sebagai bahan pertimbangan dalam penyempurnaan buku matematika siswa SMP kurikulum 2013.

\section{Metode}

Jenis penelitian ini adalah penelitian deskriptif analitik, yakni suatu penelitian yang bertujuan untuk memberikan gambaran tentang realitas pada objek yang diteliti secara objektif. Penelitian ini menekankan pada satu variabel yaitu kebenaran konsep pada buku matematika siswa SMP kurikulum 2013.

\section{Hasil dan Pembahasan}

Hasil penelitian menunjukkan bahwa dalam buku matematika siswa kelas 7 kurikulum 2013, ditemukan 26 halaman yang memuat kekeliruan. Sedangkan pada buku matematika siswa kelas 8 kurikulum 2013, 44 halaman memuat kesalahan. Ini tidak termasuk sering terjadinya kesalahan terhadap pencetakan, misalkan kesalahan dalam pengejaan, penggunaan kata depan, kurangnya penggunaan spasi, dan lain sebagainya.

Peninjauan lebih mendalam mengenai kekurangtepatan atau kesalahan yang terdapat dalam buku matematika siswa kurikulum 2013 ini dapat dilihat pada buku kelas 8. Kesalahan yang terdapat pada buku jilid 8 dengan mengambil sampel dari halaman 5 sampai dengan halaman 53 (48 halaman) sebagai berikut:

1) Banyaknya halaman, maka terdapat 16 kesalahandari 48 halaman yang diteliti sebagai sampel jadi ada 33,3 \% kesalahan.

2) Macam kesalahan adalah:

a) Pada halaman 5 sampai dengan halaman 10 buku memberikan sajian yang tidak sistimatis dan tidak lengkap.

b) Halaman 18, 19 dan 21 kepada siswa tidak ada penjelasan bahwa nama persegi dari yang kecil ke yang besar mengikuti huruf besar abjad. Kalau hal itu berpola seharusnya pemberian nama titik sudut mengkuti nama persegi panjang yaitu menggunakan indeks $\left(A_{i}\right) i=1,2,3 \ldots$.Kesalahan pemaksaan siswa harus mengikuti pola yang tidak selalu benar.

c) Halaman 42, Nyatakan bentuk aljabar kain yang digunakan untuk menjahit, penulis buku tidak cermat dalam membuat kalimat.

d) Halaman 28 makna tanda "=" disalah artikan oleh penulis buku yaitu: 
$A_{1}(4,1)=(2 \times 2,2-1)$ adalah salah, dan

$(2 \times 2,2-1)=(2(1+1),(2 \times(1-$ 1)) juga salah

Kesimpulan siswa diberi materi ajar yang salah.

e) Halaman 42, Nyatakan bentuk aljabar kain yang digunakan untuk menjahit, penulis buku tidak cermat dalam membuat kalimat.

f) Mulai halaman 46. Penggunaan simbol " $x$ " sebagai simbol perkalian di SMP seharusnya tidak digunakan sebab rawan dengan simbol variabel " $x$ ". Kesalahanan penggunaan satu simbol untuk dua macam makna.

g) Halaman 47 penggunaan huruf besar pada awal nama orang tidak dilakukan.

h) Halaman 48 contoh pengerjaan yang membingungkan siswa apalagi jika ditulis dalam buku tulis.

i) Halaman 48 Kesalahan gambar tidak lengkap.

j) Halaman 51 Penyelesaian dari $r$ masih dalam memuat variabel $x, y$, $\mathrm{p}$ dan $\mathrm{q}$. Kesalahan siswa SMP belum saatnya diberikan soal semacam itu.

k) Halaman 52, Keteledoran penulis menyamakan persegi dengan persegipanjang yang jelas merupakan dua bangun yang berbeda.

I) Halaman 53 Keteledoran pengetikan kurang 1 huruf, dan kesalahan bahwa luas = panjang $\mathrm{x}$ lebar tidak selalu benar.

Kesalahan-kesalahan yang ditemukan dalam buku matematika siswa SMP kurikulum 2013 sangat beragam. Disatu sisi, kesalahan itu dalam 5 halaman yang berurutan menyatakan bahwa penulis dalam menyusun materi ajar tidak mengikuti aturan bahwa matematika merupakan ilmu yang terstruktur, dsisi lain kesalahan hanya kurang 1 huruf dalam pengetikan 1 kata, dan di sisi yang lain lagi kalimat tidak bermakna.

Jika dibuatkan klasifikasinya, kesalahankesalahan tersebut di antaranya adalah:

1) kesalahan dan ketidaktepatan dalam penulisan kalimat,

2) ketidakjelasan dalam menuliskan perintah soal, ketidaklengkapan dalam memaparkan materi atau contoh soal,

3) kesalahan dalam perhitungan yang banyak ditemui pada contoh soal,

4) kesalahan pada gambar atau ilustrasi,

5) kesalahan konsep matematika, seperti menentukan gradien persamaan grafik garis lurus, grafik fungsi, letak titik pada koordinat kartesius, ukuran segitiga siku-siku, masalah nyata dalam kehidupan.

Kesalahan konsep juga ditemukan dalam beberapa kompetensi dasar yang berkaitan. Ini dipengaruhi oleh bagaimana konsep disajikan dalam buku. Untuk buku matematika siswa kelas 7 kurikulum 2013, kesalahan konsep terletak pada kompetensi dasar

1) 2.1 Menunjukkan perilaku konsisten dan teliti dalam melakukan aktivitas di 
rumah, sekolah, dan masyarakat sebagai wujud implementasi pemahaman tentang operasi hitung bilangan bulat dan pecahan

2) 3.1 Membandingkan dan mengurutkan berbagai jenis bilangan serta menerapkan operasi hitung bilangan bulat dan bilangan pecahan dengan memanfaatkan berbagai sifat operasi.ntuk penelitian kualitatif, bagian hasil memuat bagian-bagian rinci dalam bentuk sub topik-sub topik yang berkaitan langsung dengan fokus penelitian dan kategori-kategori.

Kompetensi ini berkaitan tentang makna bilangan positif dan negatif dalam soal yang melibatkan kegiatan sehari-hari. Selain itu, bagaimana penggunaan garis bilangan sebagai salah satu cara menyelesaikan operasi hitung bilangan juga disajikan agak rancu. Di satu sisi, siswa diminta menggunakan garis bilangan dalam menyelesaikan masalah, dengan banyaknya contoh-contoh penggunaan garis bilangan. Di sisi lain, siswa juga dituntut gar tidak menggunakan garis bilangan lagi jika bilangan yang dioperasikan merupakan bilangan yang besar.

Untuk buku matematika siswa kelas 8 kurikulum 2013 terdapat pada:

1) 3.4 Menentukan gradien persamaan dari grafik garis lurus

2) 3.5 Menyajikan fungsi dalam berbagai bentuk relasi, pasangan berurut, rumus fungsi, tabel, grafik, dan diagram
3) 3.8 Memahami Teorema Pythagoras melalui alat peraga dan penyelidikan berbagai pola bilangan

4) 3.10 Menerapkan lokasi benda dalam koordinat Kartesius dalam menjelaskan posisi relatif terhadap acuan tertentu

5) 4.3 Menggunakan pola dan generalisasi untuk menyelesaikan masalah nyata.

Terdapatnya beberapa kesalahan dalam memaknai grafik, baik melukis ataupun menempatkan titik menjadi sorotan dalam buku matematika siswa kelas 8 kurikulum 2013. Penggunaan ilustrasi atau gambar juga harus diperhatikan mengingat siswa mengkonstruksi pemahamannya dari apa yang dilihat dan dibaca. Ukuran segitiga maupun jenis segitiga yang digunakan haruslah sesuai dengan maksud yang diingin dihadapkan pada siswa. Juga pemilihan dalam penggunaan masalah nyata, tidak hanya ada, tapi juga harus memungkinkan untuk terjadi.

Selain itu, matematika memerlukan ketelitian dan kecermatan, model-model matematika salah dalam menentukan letak saja dapat memiliki arti yang sangat berbeda. Sebagai contoh "234" memiliki nilai berbeda dengan $\left(23^{4}\right)$, apalagi kekurangan satu huruf dapat berakibat fatal. Oleh karena itu banyaknya kesalahan pada buku Matematika seharusnya segera diperbaiki. Banyak pula ditemukan kalimat-kalimat ambigu atau bermakna ganda dan sulit dimengerti. 


\section{Penutup}

Dari penelitian yang telah dilakukan, diperoleh beberapa simpulan sebagai berikut:

1) Kesalahan-kesalahan pada buku matematika siswa kurikulum 2013 meliputi

a) kesalahan dan ketidaktepatan dalam penulisan kalimat,

b) ketidakjelasan dalam menuliskan perintah soal, ketidaklengkapan dalam memaparkan materi atau contoh soal,

c) kesalahan dalam perhitungan yang banyak ditemui pada contoh soal,

d) kesalahan pada gambar atau ilustrasi,

e) kesalahan konsep matematika, seperti menentukan gradien persamaan grafik garis lurus, grafik fungsi, letak titik pada koordinat kartesius, ukuran segitiga siku-siku, masalah nyata dalam kehidupan.

2) Kesalahan-kesalahan konsep terdapat pada kompetensi dasar

Untuk buku matematika siswa kelas 7 kurikulum 2013 adalah:

a) 2.1 Menunjukkan perilaku konsisten dan teliti dalam melakukan aktivitas di rumah, sekolah, dan masyarakat sebagai wujud implementasi pemahaman tentang operasi hitung bilangan bulat dan pecahan

b) 3.1 Membandingkan dan mengurutkan berbagai jenis bilangan serta menerapkan operasi hitung bilangan bulat dan bilangan pecahan dengan memanfaatkan berbagai sifat operasi.

Untuk buku matematika siswa kelas 8 kurikulum 2013 adalah:

a) 3.4 Menentukan gradien persamaan dari grafik garis lurus

b) 3.5 Menyajikan fungsi dalam berbagai bentuk relasi, pasangan berurut, rumus fungsi, tabel, grafik, dan diagram

c) 3.8 Memahami Teorema Pythagoras melalui alat peraga dan penyelidikan berbagai pola bilangan

d) 3.10 Menerapkan lokasi benda dalam koordinat Kartesius dalam menjelaskan posisi relatif terhadap acuan tertentu

e) 4.3 Menggunakan pola dan generalisasi untuk menyelesaikan masalah nyata

3) Formulasi masukan sebagai bahan pertimbangan dalam penyempurnaan buku matematika siswa SMP kurikulum 2013 dapat berupa perubahan kalimat atau instruksi soal, perubahan struktur dalam pembahasan contoh soal, penggunaan masalah kontekstual yang sesuai, dan pemaparan materi sesuai konsep matematika.

Saran yang dapat diberikan dari hasil penelitian ini adalah Analisis buku dapat dilanjutkan untuk buku matematika siswa kurikulum 2013 tingkat SMA dan buku guru.

\section{Daftar Pustaka}

Ariyadi Wijaya. (2012). Pendidikan Matematika Realistik: Suatu Alternatif 
Pendekatan Pembelajaran

Matematika, Yogyakarta: Graha IImu

Ahmad Susanto. (2013) .Teori Belajar dan

Pembelajaran di Sekolah Dasar.

Jakarta: Kencana Prenada Media

Group

Badan Standar Nasional Pendidikan

(BSNP). (2006). Kurikulum dalam Konteks Standar Nasional

Pendidikan.

Blancard, A. (2001). Contextual Teaching and Learning. B.E.S.T.

Bishop, A. J., Mellin, O., Stieg \& van Doormolen, J. (1991). Mathematical Knowledge: Its Growth Through Teaching. London: Kluwer Academic Publisher.

Erman Suherman, dkk. (2003).Strategi Pembelajaran Matematika Kontemporer. Bandung : JICA UPI

Gravemeijer, K. P. E. (1994). Developing Realistic Mathematics Education. CD$B$ Press Freudenthal Institute, Utrecht, The Netherlands.

Gredler, M. E. (1986). Learning and instruction:Theory into Practice. Wiley

Periodicals, Inc: New York

Hamzah B Uno. (2007). Perencanaan Pembelajaran. Jakarta: Bumi Aksara.

Hairur Rahman. (2007). Indahnya Matematika dalam Al-Qur'an. Malang : UIN Malang Press.

Heinich, R., Smaldino, S. E., \& Russel, J. D. (2004). Instructional Technology and Media for Learning. Pearson Education.
Hergenhahn, B. R \& Olson, M. H. (1982). An Introduction to the Theories of Learning. Prentice Hall.

Ibrahim dan Suparni. (2012). Pembelajaran Matematika Teori dan Aplikasinya. Yogyakarta: Suka Press UIN Sunan Kalijaga Yogyakarta.

Johnson, E.B. (2002). Contextual Teaching and Learning. California: Corwin Press, Inc.

Kemdikbud. (2013). Pengembangan Kurikulum 2013. Paparan Mndikbud dalam Sosialisasi Kurikulum 2013. Jakarta: Kemdikbud

Kemdikbud. (2013). Kompetensi Dasar Matematika SMP/MTs. Jakarta :Kemdikbud

Kemdikbud. (2013). Pendekatan Scientific (IImiah) dalam Pembelajaran. Jakarta: Pusbangprodik.

Martiyono. (2012). Perencanaan Pembelajaran. Kebumen: Aswaja Pressindo

Mazur, B., Jerison, D., \& Schmid, W. (1999). Current Development in Mathematics. International Press of Boston.

Nur, M. dkk. (2001). Pengembangan Perangkat Pembelajaran MIPA untuk Siswa SLTP Kategori

Kontekstual Cawu 1. Laporan Penelitian. Tidak diterbitkan.

Orton, A. (1987) . Learning Mathematics. London: Casel Educational Limited.

Pusat Perbukuan. (2005). Peraturan Menteri Pendidikan Nasional Nomor 11 Tahun 2005 tentang Buku Teks 
Pelajaran. Jakarta: Departemen Pendidikan Nasional.

Riedesel, C. A., Schwarts, J. E \& Doughlas, H. (1996). Teaching Elementary School Mathematics. Boston: Allyn and Bacon.

Romizowski, A. (1990). Design Instructional systems: Decisionmaking in course planning and curriculum design. London: Kogan page.

Slavin, R. (2005). Cooperative Learning, teori, riset, dan praktek. Nusa Media: Bandung.

Sri Wardhani. (2006). Contoh Silabus dan RPP Matematika SMP. Yogyakarta: PPPG Matematika.

Sri Wardhani. (2010). Implikasi Karakteristik Matematika dalam Penacapaian Tujuan Mata Pelajaran Matematika di SMP/MTs. Departemen Pendidikan Nasional Direktorat Jenderal Peningkatan Mutu Pendidik Dan Tenaga Kependidikan Pusat Pengembangan dan Pemberdayaan Pendidik Dan Tenaga Kependidikan (PPPPTK) Matematika.

Trianto. (2009) .Mendesain Model Pembelajaran Inovatif-Progresif. Surabaya: Prenada Media Group.

Trianto. (2010). Mendesain model Pembelajaran Inovatif-Progesif:
Konsep, Landasan dan Implementasinya pada Kurikulum Tingkat Satuan Pendidikan (KTSP). Jakarta: Kencana.

Williams, D. L. 2007. The What, Whay, and How of Contextual Teaching in Mathematics Classroom. Mathematics Teacher. NCTM. 100(8), 572-575

\section{Riwayat Hidup PenUlis}

Ilham Rizkianto, M. Sc.

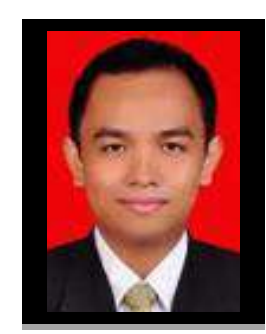

Lahir di Ponorogo, 8 Maret 1987. Merupakan staf pengajar di Universitas Negeri Yogyakarta. Menyelesaikan pendidikan dengan program studi S1 Pendidikan Matematika di Universitas Pendidikan Ganesha, Singaraja, Bali dan lulus tahun 2009; studi S2 program studi Pendidikan Matematika di Universitas Sriwijaya, Palembang, Sumatera Selatan dan Utrecht University, Utrecht, Belanda dan lulus tahun 2012.

\section{Prof. Dr. Rusgianto Heri Santosa, M. Pd.}

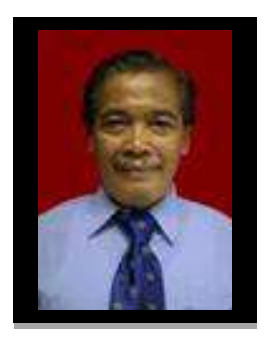
Lahir di Yogyakarta, 17 April 1949. Merupakan staf pengajar di Universitas Negeri Yogyakarta. Menyelesaikan pendidikan denga program studi S1 Pendidikan Matematika di IKIP Yogyakarta dan lulus tahun 1981; studi S2 IKIP Jakarta, lulus tahun 1985; dan studi S3 di Universitas Negeri Jakarta dan lulus tahun 2002. 